\title{
Cenozoic Reconstructions of the Australia-New Zealand-South Pacific Sector of Antarctica
}

\author{
Steven C. Cande \\ Scripps Institution of Oceanography, University of California, San Diego, California \\ Joann M. Stock \\ Seismological Laboratory, California Institute of Technology, Pasadena, California
}

Reconstructions are presented documenting the relative motion of the Australia, Antarctic and Pacific plates since Chron 27 (61.1 Ma). In addition to the motion of the major plates, the reconstructions show the relative motion between East and West Antarctica and the continental fragments that make up the South Tasman Rise. Recent observations that are used in making these reconstructions include the mapping of seafloor spreading magnetic anomalies in the Adare basin, northeast of Cape Adare, which recorded roughly $150 \mathrm{~km}$ of opening between East and West Antarctica between Chrons 20 (43.8 Ma) and 8 (26.6 Ma). In addition, magnetic and bathymetric observations from the Iselin Rift, northeast of the Iselin Bank, and from the Emerald Fracture Zone, along the western boundary of Pacific-Antarctic spreading, document the rotation of the Iselin Bank between Chrons 27 and 24 (53.3 Ma). Our reconstructions indicate that there was a total of about $200 \mathrm{~km}$ of separation between East and West Antarctica in the northern Ross Sea region in the Cenozoic. These reconstructions document the development of a deep-water passageway between Australia and Antarctica as the South Tasman Rise clears the final piece of the Antarctic continental margin around Chron 13 (33.5 Ma).

\section{INTRODUCTION}

The opening of a deepwater passageway between Australia and Antarctica in the late Eocene and early Oligocene [Kennett et al., 1975; Exon, Kennett, Malone et al., 2001], and the subsequent opening of the Drake Passage a few million years later [Barker, 2001], were critical events in the development of the Antarctic Circumpolar Current and the ensuing cooling of the Earth's

The Cenozoic Southern Ocean: Tectonics, Sedimentation, and Climate Change Between Australia and Antarctica Geophysical Monograph Series 151

Copyright 2004 by the American Geophysical Union.

10.1029/151GM02 climate in the late Tertiary. In this paper we present a series of plate reconstructions showing how the Tasmanian Gateway developed as a result of the relative motion of the Australia, Antarctic, and Pacific plates and several small continental fragments. The motion of these plates has been broadly known since the mid-1970's [e.g. Weissel and Hayes, 1972; Molnar et al., 1975; Weissel et al., 1977]. However, there were large uncertainties in the early studies because of the poor magnetic and bathymetric data coverage in many areas of the southern oceans. With the determination of a detailed global gravity field from satellite altimetry data (Figure 1) [Sandwell and Smith, 1997], revealing the location of fracture zones and other tectonic features in the most remote portions of the oceans, and with the advent of GPS-navigated, swathmap bathymetry surveys, there has been considerable improvement in our understanding 


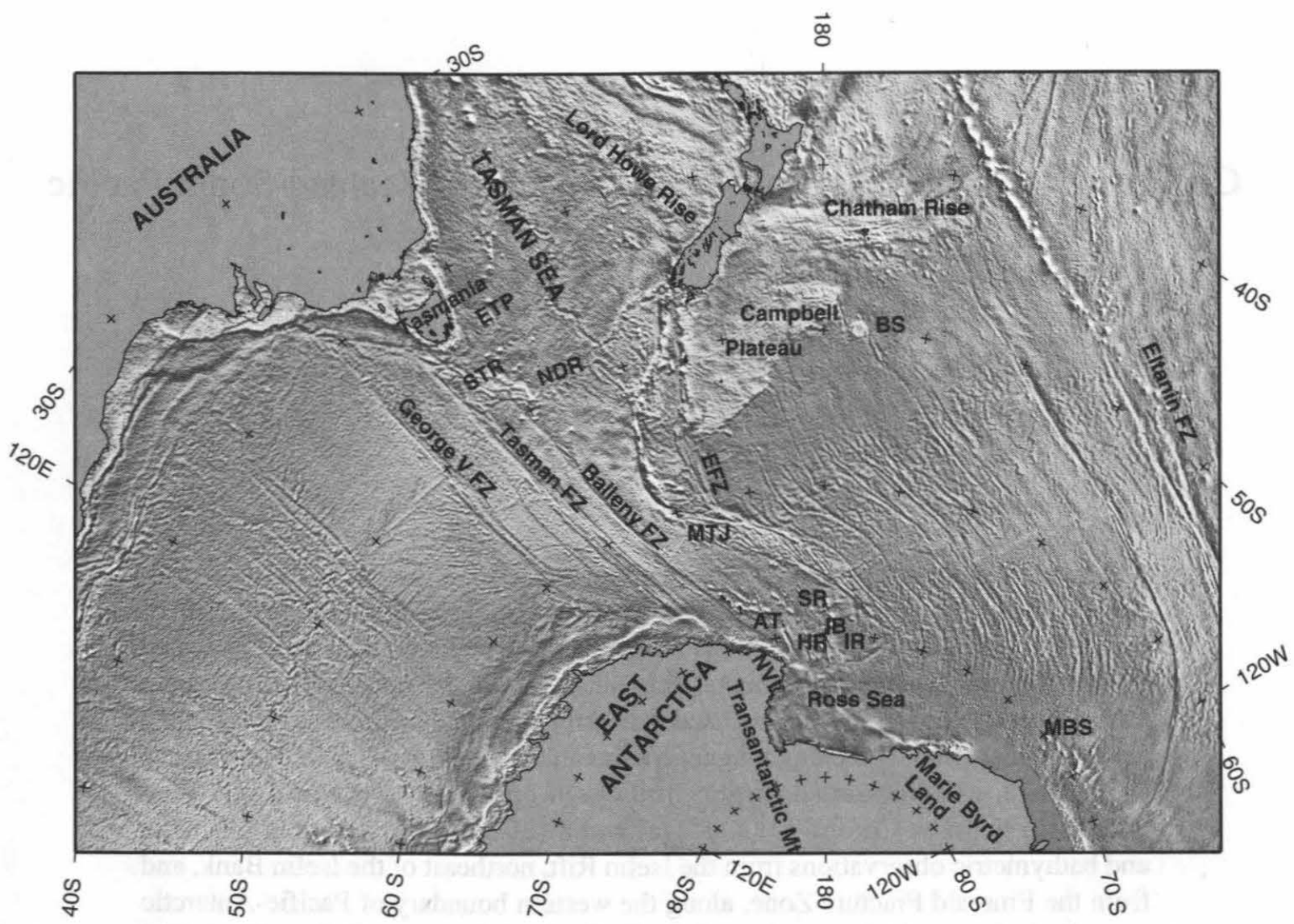

Figure 1. Grey-scale map of satellite gravity for the region around Antarctica and relevant tectonic features mentioned in the text. Gravity field is from Sandwell and Smith [1997]. Regions above sea level are shown in grey and submerged continental regions in white. AT = Adare Trough. $\mathrm{BS}=$ Bollons Seamount. EFZ $=$ Emerald Fracture Zone. ETP $=$ East Tasman Plateau. $\mathrm{HR}=$ Hallett Ridge. IB $=$ Iselin Bank. IR = Iselin Rift. MBS = Marie Byrd Seamounts. MTJ = Macquarie Triple Junction. NDR = Nella Dan Rift. NVL = Northern Victoria Land. $\mathrm{SR}=$ Scott Rift. $\mathrm{STR}=$ South Tasman Rise. Map is a stereographic projection with a view point of $90^{\circ} \mathrm{S}, 180^{\circ} \mathrm{E}$.

of the tectonics of the southern oceans. These developments include better constraints on the relative motion between the Pacific and Antarctic plates [Cande et al., 1995], a better understanding of the rifting and seafloor spreading history between the Pacific and Australia plates [Sutherland, 1995; Keller, 2003], marine magnetic anomaly constraints on the Cenozoic motion between East and West Antarctica [Cande et al., 2000a], and better constraints on the motion between the eastern and western portions of the South Tasman Rise [Royer and Rollet, 1997; Exon et al., 1996].

We use these newer constraints to derive a series of plate reconstructions of the Pacific-Antarctic-Australia region. The oldest reconstruction that we present is for Chron 27 (61.1 Ma; Cande and Kent, 1995). We selected this time as a starting point because uncertainties in reconstructions become substantially greater prior to Chron 27 . A major problem is that the spreading rate on the Southeast Indian ridge (SEIR) was very slow $(<10 \mathrm{~mm} / \mathrm{yr}$; all spreading rates cited in this paper are half rates) prior to anomaly 20 (43.8 Ma) [e.g. Veevers et al., 1990] and it is very difficult to identify anomalies older than anomaly 24 . Consequently, there is considerable controversy about the identification of the oldest anomalies in the Australia-Antarctic basin. For example, although it has been proposed that anomalies as old as anomaly 34 (83 Ma) are present in the Australia-Antarctic Basin [Cande and Mutter, 1982] and that seafloor spreading started around $95 \mathrm{Ma}$ (Veevers, 1986), recent seismic reflection data suggest that the oldest seafloor spreading anomaly is anomaly 33 (79 Ma) [Sayers et al., 2001]. In the area immediately west of Tasmania, the oldest anomaly definitely identified by Royer and Rollet [1997] was anomaly 18 (40 Ma). Similarly, although there are good constraints on the relative motion between East and West Antarctica back to Chron 20 [Cande et al., 2000a], and a rough estimate can be made for East-West Antarctic motion based on seafloor 
spreading constraints back to Chron 27 [Cande et al., 2000b], there are very few constraints on East-West Antarctica separation prior to Chron 27.

\section{CONSTRAINTS}

The basic data for these reconstructions are rotation parameters for pairs of individual plates, generated from magnetic anomaly and fracture zone data. These rotation parameters and the distribution of the magnetic anomaly and fracture zone data allow us to define seafloor isochrons on each plate, to visualize the changes in the plate configuration through time. The complete set of isochrons is shown in Figure 2. In addition we include trends of a few important tectonic features discussed in the text such as selected triple junction traces, rifted margins, and fossil spreading centers.
The isochrons that we used in these reconstructions are tied to specific rotation parameters, as follows: for each time, we rotate anomaly picks and fracture zone locations from one plate back to the conjugate plate. We then use both the rotated and unrotated anomaly and fracture zone positions to draw the isochron on the conjugate plate. The isochron is digitized and then rotated back to the initial plate. In this way, the isochrons from the two plates are so defined as to superimpose exactly when reconstructed by the appropriate rotation. In the following section we describe the data sets and rotations in detail.

\section{Australia-Antarctica}

The basic spreading history on the Southeast Indian Ridge (SEIR) was established by Weissel and Hayes [1972], who

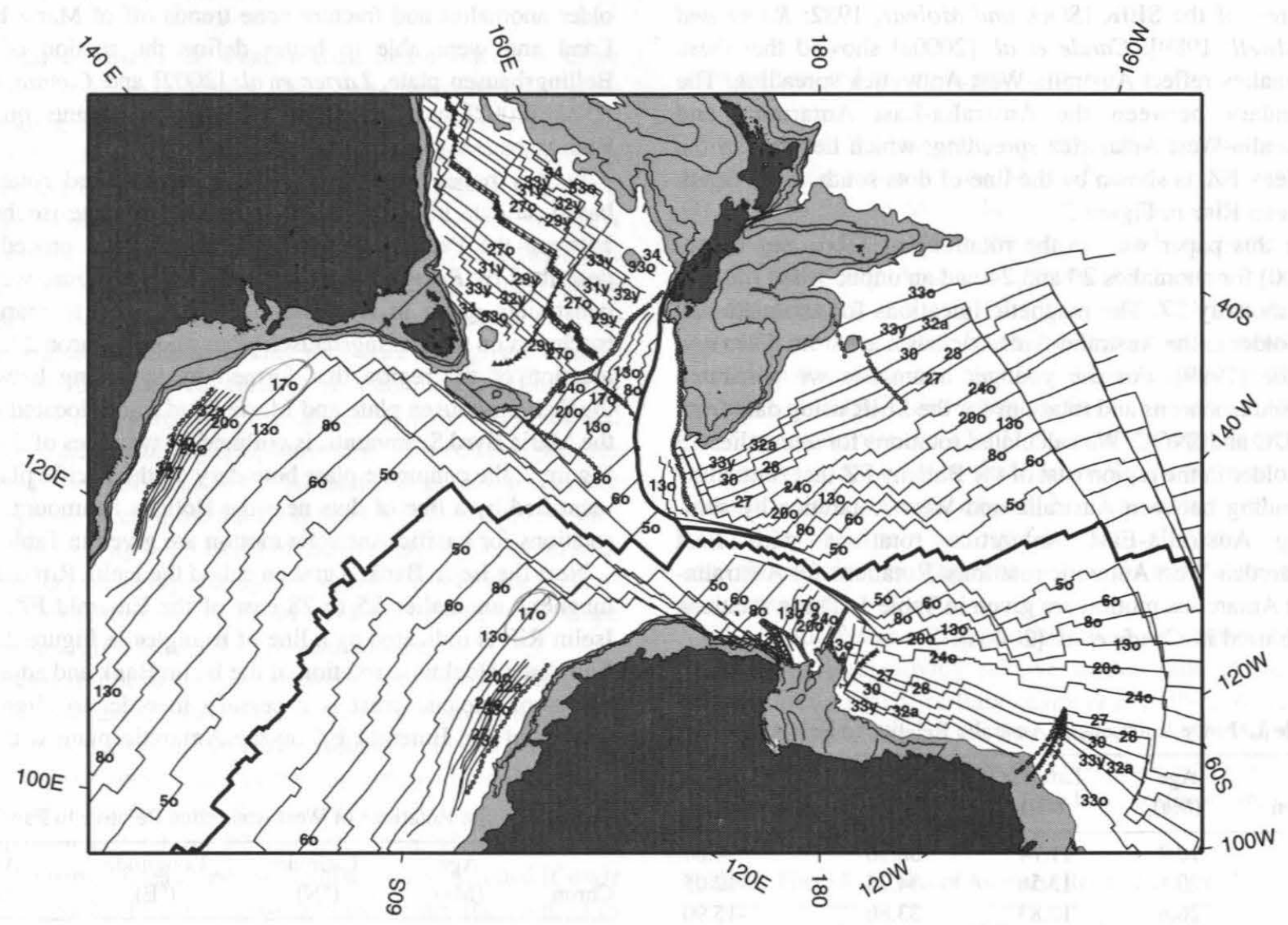

Figure 2. Map of selected isochrons in the Australia-New Zealand-South Pacific oceanic sector. Dotted lines represent traces of former triple junctions (that is, boundaries between provinces of crust formed by spreading at different spreading centers) except for south of Australia and in the conjugate region of Antarctica, where the dotted line indicates the magnetic quiet zone boundary [Tikku and Cande, 1999]. Lines of triangles represent failed spreading centers. Ages of isochrons, from Cande and Kent [1995] are as follows: 5o, 10.9 Ma; 6o, $20.1 \mathrm{Ma} ; 8 \mathrm{o}, 26.6 \mathrm{Ma} ; 13 \mathrm{o}, 33.5 \mathrm{Ma} ; 17 \mathrm{o}, 37.5 \mathrm{Ma} ; 20 \mathrm{o}, 43.8 \mathrm{Ma} ; 24 \mathrm{o}, 53.3 \mathrm{Ma} ; 27,61.1 \mathrm{Ma} ; 27 \mathrm{o}, 61.2 \mathrm{Ma} ; 28,62.5 \mathrm{Ma} ; 29 \mathrm{y} ; 30,65.6$ Ma; 31y, 67.7 Ma; 32y, 71.1 Ma; 32a, 71.5 Ma; 33y, 73.6 Ma; 33o, 79.1 Ma; 34, 83.0 Ma. Bathymetric contours are 1000, 2000, and 3000 m contours [IHO/IOC/CHS, 1984]. Map projection same as Figure 1. 
identified magnetic anomalies back to anomaly 22. Cande and Mutter [1982] showed that the spreading rate on the SEIR prior to anomaly 18 was very slow $(<10 \mathrm{~mm} / \mathrm{yr})$ and proposed that the oldest anomaly was anomaly 34 . Veevers [1986] suggested that the Continent-Ocean Boundary was located at the seaward limit of the magnetic quiet zones found adjacent to both the Australia and Antarctic continental margins and calculated that seafloor spreading started around $95 \mathrm{Ma}$. Tikku and Cande [1999, 2000] analyzed magnetic anomaly data collected by the Japanese National Oil Company (JNOC) off of Wilkes Land (Ishihara et al., 1996) and derived a revised set of rotations for the early opening history (Chron 20 and older). An important aspect of the spreading history on the SEIR is that east of the Balleny Fracture Zone (FZ) (see Figure 1), anomalies older than anomaly $8(26.6 \mathrm{Ma})$ are spreading faster than would be expected for Australia-East Antarctica spreading based on the rest of the SEIR [Stock and Molnar, 1982; Royer and Sandwell, 1989]. Cande et al. [2000a] showed that these anomalies reflect Australia-West Antarctica spreading. The boundary between the Australia-East Antarctica and Australia-West Antarctica spreading, which lies east of the Balleny FZ, is shown by the line of dots south of the South Tasman Rise in Figure 2.

In this paper we use the rotations of Tikku and Cande [2000] for anomalies 20 and 24 and an unpublished rotation for anomaly 27 . The magnetic lineations for anomalies 20 and older in the Australia-Antarctic basin are from Tikku and Cande [1999]. For the younger anomalies we generated revised isochrons and rotations for the SEIR using data from NGDC and JNOC. We calculated rotations for anomalies 13 and older in the region east of the Balleny FZ that formed by spreading between Australia and West Antarctica by summing Australia-East Antarctica rotations with East Antarctica-West Antarctic rotations. Rotations for AustraliaEast Antarctica motion are given in Table 1. These rotations were used in Cande et al. [2000a].

Table 1. Finite Rotations of Australia Relative to East Antarctica

\begin{tabular}{lcccr}
\hline Chron & $\begin{array}{c}\text { Age } \\
(\mathrm{Ma})\end{array}$ & $\begin{array}{c}\text { Latitude } \\
\left({ }^{\circ} \mathrm{N}\right)\end{array}$ & $\begin{array}{c}\text { Longitude } \\
\left({ }^{\circ} \mathrm{E}\right)\end{array}$ & $\begin{array}{r}\text { Angle } \\
(\mathrm{Deg})\end{array}$ \\
\hline 50 & 10.9 & 11.74 & 38.16 & -6.80 \\
60 & 20.1 & 13.56 & 34.24 & -12.05 \\
80 & 26.6 & 13.83 & 33.80 & -15.90 \\
130 & 33.5 & 13.71 & 34.11 & -20.48 \\
200 & 43.8 & 15.07 & 31.78 & -24.55 \\
240 & 53.3 & 10.39 & 35.59 & -25.15 \\
$27 \mathrm{~m}$ & 61.1 & 7.86 & 35.80 & -25.54 \\
\hline
\end{tabular}

Ages are from Cande and Kent (1995).

Rotations for 200 and 240 are from Tikku and Cande (2000).

Counterclockwise rotations are positive angles.

\section{Pacific-Antarctica}

In the first comprehensive study of Pacific-Antarctica motion, Molnar et al. [1975] identified anomalies as old as anomaly 32 and estimated that the onset of seafloor spreading was roughly $81 \mathrm{Ma}$. Stock and Molnar [1987] showed that the magnetic anomalies and fracture zones that formed during the earliest phase of spreading (prior to Chron 25) require that there was a separate plate, named the Bellingshausen plate, east of the Marie Byrd Seamounts, and that true PacificAntarctic motion prior to Chron 25 was confined to the region between the Campbell Plateau and Marie Byrd Land. Mayes et al. [1990] used satellite-derived gravity data to help constrain revised Pacific-Antarctic rotations. Cande et al. [1995] collected magnetic and swathmap bathymetry data along a high latitude flowline which provided strong constraints on the rotations. Heinemann et al. [1999] analyzed data from the older anomalies and fracture zone trends off of Marie Byrd Land and were able to better define the motion of the Bellingshausen plate. Larter et al. [2002] and Cunningham et al. [2002] have reported additional constraints on the Bellingshausen plate anomaly pattern.

In this paper we use previously unpublished rotations based on data in Cande et al. [1995] to generate isochrons between the Pacific and Antarctic plate, using procedures described by Royer and Chang [1991]. In addition, we use constraints given in Heinemann et al. [1999] to map the isochrons on the Bellingshausen plate prior to Chron 27. The location of the region that formed by spreading between the Bellingshausen plate and Marie Byrd Land, located near the Marie Byrd Seamounts, is outlined by two lines of dots in Figure 2; the conjugate plate boundary on the Pacific plate is identified by a line of dots near the Bollons Seamount. The rotations for Pacific-Antarctic motion are given in Table 2.

Near the Iselin Bank, a graben called the Iselin Rift offsets magnetic anomalies 25 to 28 east of the Emerald FZ. The Iselin Rift is indicated by a line of triangles in Figure 2. We find that a clockwise rotation of the Iselin Bank and adjacent pieces of oceanic crust is necessary in order to align the strands of the Emerald FZ on the Antarctic plate with the

Table 2. Finite Rotations of West Antarctica Relative to Pacific

\begin{tabular}{lcccr}
\hline Chron & $\begin{array}{c}\text { Age } \\
(\mathrm{Ma})\end{array}$ & $\begin{array}{c}\text { Latitude } \\
\left({ }^{\circ} \mathrm{N}\right)\end{array}$ & $\begin{array}{c}\text { Longitude } \\
\left({ }^{\circ} \mathrm{E}\right)\end{array}$ & $\begin{array}{r}\text { Angle } \\
(\mathrm{Deg})\end{array}$ \\
\hline 50 & 10.9 & 70.86 & -75.96 & -9.71 \\
60 & 20.1 & 74.15 & -68.70 & -16.90 \\
80 & 26.6 & 74.77 & -66.94 & -21.83 \\
130 & 33.5 & 74.52 & -63.21 & -27.67 \\
200 & 43.8 & 74.78 & -51.55 & -35.32 \\
240 & 53.3 & 73.63 & -52.50 & -40.03 \\
$27 \mathrm{~m}$ & 61.1 & 71.46 & -55.07 & -45.20 \\
\hline
\end{tabular}


Table 3. Finite Rotation of Iselin Bank Relative to West Antarctica

\begin{tabular}{lcccc}
\hline Chron & $\begin{array}{c}\text { Age } \\
(\mathrm{Ma})\end{array}$ & $\begin{array}{c}\text { Latitude } \\
\left({ }^{\circ} \mathrm{N}\right)\end{array}$ & $\begin{array}{c}\text { Longitude } \\
\left({ }^{\circ} \mathrm{E}\right)\end{array}$ & $\begin{array}{c}\text { Angle } \\
(\text { Deg.) }\end{array}$ \\
\hline $24 \mathrm{o}$ & 53.3 & -73.0 & 175.0 & 0.0 \\
$27 \mathrm{~m}$ & 61.1 & -73.0 & 175.0 & -7.0 \\
\hline
\end{tabular}

conjugate strands of the Emerald FZ on the Pacific plate prior to Chron 24. Consequently, we conclude that the Iselin Rift formed when there was a counterclockwise rotation of the Iselin Bank and adjacent pieces of oceanic crust, including the Emerald FZ north of the Iselin Rift, between Chrons 27 and 24 [Cande et al., 2000b]. We incorporate this rotation (Table 3) in our reconstructions (see discussion under chron 27 reconstruction later in this paper).

\section{East-West Antarctic Motion}

Oceanic crust in the western Ross Sea northeast of Cape Adare, Northern Victoria Land, was generated by slow spreading between East and West Antarctic between Chrons 20 and 8 [Cande et al., 2000a]. The boundary of the crust generated by this spreading is shown in Figure 2 by two lines of dots. We have concluded that the Adare Trough, a prominent graben northeast of Cape Adare, is a fossil rift valley that formed when spreading in the Adare Basin ceased around Chron 8. Spreading rates calculated from magnetic anomalies straddling the Adare Trough are consistent with the faster Australia-West Antarctic spreading rates observed in the region east of the Balleny $\mathrm{FZ}$ discussed above. Cande et al. [2000a] showed that the rotation pole for this episode of East-West Antarctic separation was far enough removed from the Ross Sea region to require a substantial opening $(\sim 150 \mathrm{~km})$ of the western Ross Sea basins. The effect of incorporating this rotation in our older reconstructions is to close the Iselin Bank back towards the Cape Adare margin in the older reconstructions.

Although not as well constrained, our reconstructions for Chrons 24 and 27 suggest that there was some additional opening between East and West Antarctica in that time interval. The strongest evidence for this extension is the appearance of a gap between the Lord Howe Rise and Campbell Plateau in our Chron 27 reconstruction, if no additional motion between East and West Antarctica is included [Cande et al., 2000b]. In our reconstructions we use the rotation of Cande et al. [2000a] to close up the basins between Cape Adare and the Hallett Ridge by roughly $150 \mathrm{~km}$ between Chrons 8 and 20, and we use the same pole with a small incremental angle to close these basins by an additional $50 \mathrm{~km}$ between Chrons 24 and 27 (Table 4). The timing of this earlier stage of separation is poorly constrained and it may have occurred at a slower rate over the entire interval
Table 4. Finite Rotation of East Antarctica Relative to West Antarctica

\begin{tabular}{lcccc}
\hline Chron & $\begin{array}{c}\text { Age } \\
(\mathrm{Ma})\end{array}$ & $\begin{array}{c}\text { Latitude } \\
\left({ }^{\circ} \mathrm{N}\right)\end{array}$ & $\begin{array}{c}\text { Longitude } \\
\left({ }^{\circ} \mathrm{E}\right)\end{array}$ & $\begin{array}{c}\text { Angle } \\
(\text { Deg. })\end{array}$ \\
\hline 80 & 26.6 & -18.15 & -17.85 & 0.0 \\
130 & 33.5 & -18.15 & -17.85 & -0.70 \\
$20 \mathrm{o}$ & 43.8 & -18.15 & -17.85 & -1.70 \\
240 & 53.3 & -18.15 & -17.85 & -1.70 \\
$27 \mathrm{~m}$ & 61.1 & -18.15 & -17.85 & -2.20 \\
\hline
\end{tabular}

between Chrons 27 and 20. Note that any relative motion between East and West Antarctica during this time interval (Chrons 27 to 20) could only have been located in the region between the South Tasman Rise and the Hallett Ridge, because the older isochrons on either side of these features on the SEIR and the Pacific-Antarctic ridge are not obviously deformed.

\section{Tasman Sea and South Tasman Rise}

The Tasman Sea was generated by seafloor spreading that started a little before Chron 34 (83 Ma) and ended shortly after Chron 24 (53 Ma) [Hayes and Ringis, 1973; Weissel and Hayes, 1977]. During this period the Lord Howe Rise rotated away from Australia. Because the Lord Howe Rise did not originate as a single rigid continental fragment, but instead as many smaller fragments, the opening history of this basin was quite complex [e.g. Gaina et al., 1998]. We have used isochrons and rotations from Gaina et al. [1998] for our reconstructions (Table 5). Seafloor spreading was only actively occurring in the Tasman Sea in our two oldest reconstructions (Chrons 24 and 27). The Lord Howe Rise had consolidated into one rigid block by Chron 27, so we treat this continental fragment as a single rigid plate in our reconstructions.

The South Tasman Rise consists of two continental fragments that were moving relative to Australia in the late Cretaceous and early Tertiary [Exon et al., 1996; Royer and Rollet, 1997]. Prior to roughly Chron 30 (67 Ma) these pieces were attached to Antarctica and there was a period of either continental stretching or slow seafloor spreading

Table 5. Finite Rotations of Australia Relative to Lord Howe Rise

\begin{tabular}{lcccc}
\hline Chron & $\begin{array}{c}\text { Age } \\
(\mathrm{Ma})\end{array}$ & $\begin{array}{c}\text { Latitude } \\
\left({ }^{\circ} \mathrm{N}\right)\end{array}$ & $\begin{array}{c}\text { Longitude } \\
\left({ }^{\circ} \mathrm{E}\right)\end{array}$ & $\begin{array}{c}\text { Angle } \\
(\text { Deg. })\end{array}$ \\
\hline $24 \mathrm{y}$ & 52.4 & -14.19 & 130.41 & 0.0 \\
$24 \mathrm{o}$ & 53.3 & -14.19 & 130.41 & 0.72 \\
260 & 57.9 & -16.93 & 136.23 & 3.79 \\
$27 \mathrm{o}$ & 61.3 & -4.65 & 131.51 & 4.43 \\
\hline
\end{tabular}

Rotations are from Gaina et al. (1998). 
between Tasmania and Antarctica [Exon et al., 1997; Royer and Rollet, 1997]. Around Chron 30 the locus of separation jumped to the south and rifted the eastern part of the South Tasman Rise from Antarctica, possibly leaving a fossil spreading center south of Tasmania [Royer and Rollet, 1997]. We show the location of this fossil spreading center with a line of triangles in Figure 2. Around Chron 30 spreading developed between Australia and West Antarctica at the site of the Nella Dan Rift (in the South Tasman Sea) and Scott Rift (north of the Iselin Bank) [Lawver and Gahagan, 1994; Cande et al., 2000a]. The boundary between Australia and Antarctica jumped southwards again around Chron 18 (40 Ma), at which time the western South Tasman Rise was split off from Antarctica and joined to the eastern South Tasman Rise [Royer and Rollet, 1997]. In our reconstructions we use a slightly different scenario than that used by Royer and Rollet [1997] for the pieces of the South Tasman Rise, in as much as we have the western South Tasman Rise separating from Antarctica at Chron 20 instead of Chron 18, but the differences are barely visible in the reconstructions.

\section{Southeast Tasman Sea and the Emerald Basin}

Starting around Chron 20 there was seafloor spreading along the Pacific-Australia plate boundary south of New Zealand [Weissel et al., 1977; Sutherland, 1995]. This episode of seafloor spreading generated the oceanic crust in the Emerald Basin and Southeast Tasman Ocean Crust (STOC). Starting around $31 \mathrm{Ma}$, spreading became more and more oblique until, around $12 \mathrm{Ma}$, motion along the boundary became essentially strike-slip [Lamarche et al., 1997]. Several recent studies have mapped the fracture zones and anomalies in these basins [Massell et al., 2000; Wood et al., 2000; Keller, 2003]. We show isochrons for anomalies 8,13 and 17 based on data presented in Keller [2003]. In our reconstructions, the relative motion of these two formerly conjugate pieces of ocean crust is determined by the circuit linking the Australia (Lord Howe Rise), East Antarctica, West Antarctica and Pacific plates.

\section{RECONSTRUCTIONS}

In the following reconstructions (Figures 3a-h) we show the tectonic evolution of the Australia, New Zealand and Pacific sector of Antarctica from Chron 27 to present. The specific times of the reconstructions are Chrons $27 \mathrm{~m}(61.1$ Ma), 24o (53.3 Ma), 20o (43.8 Ma), 13o (33.5 Ma), 8o (26.6 $\mathrm{Ma}), 60(20.1 \mathrm{Ma})$ and $50(10.9 \mathrm{Ma})$, where " $\mathrm{m}$ " and "o" refer to the middle and old end of the normal polarity intervals, respectively. The objective of these figures is to show the evolution of the oceanic crustal regions and to indicate the constraints that exist from magnetic anomalies and fracture zones on the motion of the surrounding continental plates. However, no attempt has been made to depict the actual location of plate boundaries where they cut through continents since in many cases these are poorly known. For example, we do not show the location of the boundary between the Campbell Plateau and Lord Howe Rise in these reconstructions other than along the present day Alpine Fault. In addition we do not attempt to reconstruct the plate boundary that must have existed on the north side of the Lord Howe Rise and North Island of New Zealand. A discussion of the implications of these reconstructions for the continental areas is given in Stock and Cande [2002]. East Antarctica is held fixed in all of the reconstructions. Active plate boundaries are shown by bold lines, fossil spreading centers by lines of triangles, and triple junction traces and oceanic rifted boundaries by lines of dots.

\section{Chron 27m (61.1 Ma, Figure 3a)}

At Chron 27 moderate spreading ( 20 to $30 \mathrm{~mm} / \mathrm{yr}$ ) was occurring in the Tasman Sea and on the Pacific-Antarctic ridge and very slow spreading $(<10 \mathrm{~mm} / \mathrm{yr})$ was occurring on the Australia-Antarctic ridge. Very slow spreading between Australia and Antarctica would have recently become established (at Chron 30; $67 \mathrm{Ma}$ ) along the Nella Dan and Scott rifts northeast of the South Tasman Rise, extending out to a triple junction at the intersection with the Tasman Sea and Pacific-Antarctic ridges. The Lord Howe Rise is likely to have been part of the Pacific plate at this time; it would require a quadruple junction or two nearby triple junctions in the South Tasman Sea (between the Pacific, Lord Howe Rise, Australia and Antarctic plates) if the Pacific plate and Lord Howe Rise were not joined together. Motion between the Bellingshausen plate and Antarctica would have recently ended and Pacific-Antarctic spreading would now be continuous, and defined by a single rotation, between the Emerald FZ and the Eltanin FZ.

In this reconstruction the Iselin Bank has been rotated $7^{\circ}$ clockwise relative to West Antarctica about an Euler pole in the western Ross Sea $\left(73^{\circ} \mathrm{S}, 175^{\circ} \mathrm{E}\right)$ in order to close up the Iselin Rift and align the conjugate splays of the Emerald FZ. This time also marks the onset of Cenozoic motion between East and West Antarctica. The basins of the northern Ross Sea have been closed by about $200 \mathrm{~km}$, consisting of $150 \mathrm{~km}$ between Chrons 8 and 20 and $50 \mathrm{~km}$ between Chrons 24 and 27 , and the Iselin Bank has been restored to a position adjacent to the continental margin of Cape Adare. Although there are no magnetic anomalies in the eastern part of the Australia-Antarctic Basin, we have indicated the approximate location of the spreading ridge that must have connected the slow spreading anomalies of the Australia-Antarctic Basin with the long transform faults west of Tasmania. 

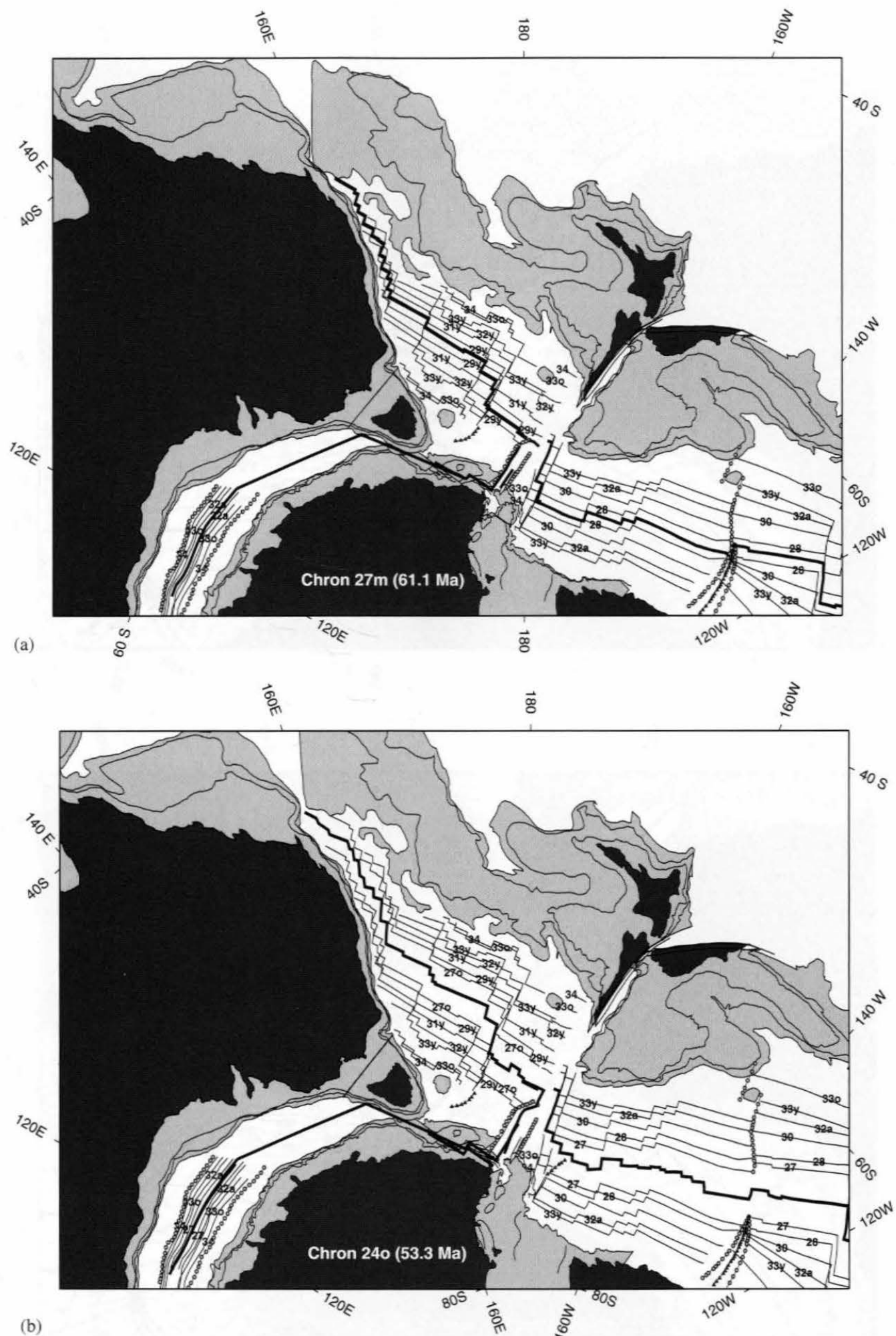

Figure 3. Tectonic reconstructions of the Pacific, Antarctic and Australia plates for a) Chron 27m, b) 24o, c) 20o, d) 13o, e) 8o, f) 6o, g) 5o and h) present showing the development of a deepwater passageway between Australia and Antarctica. Light grey stippling designates areas shallower than $3000 \mathrm{~m}$. See text for detailed description of the reconstructions. East Antarctica is held fixed. Map projection same as Figure 1. 

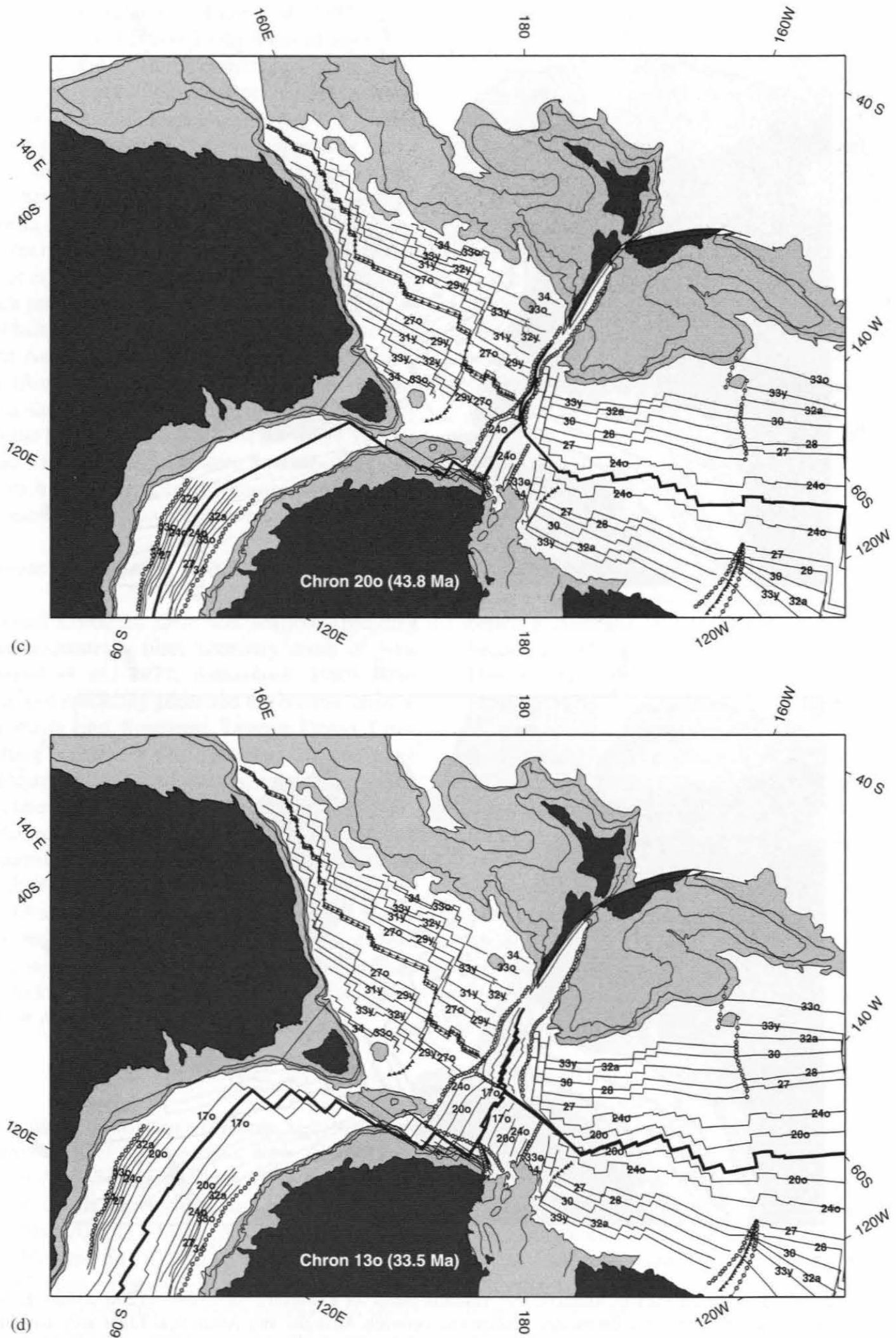

Figure 3. (Continued). 

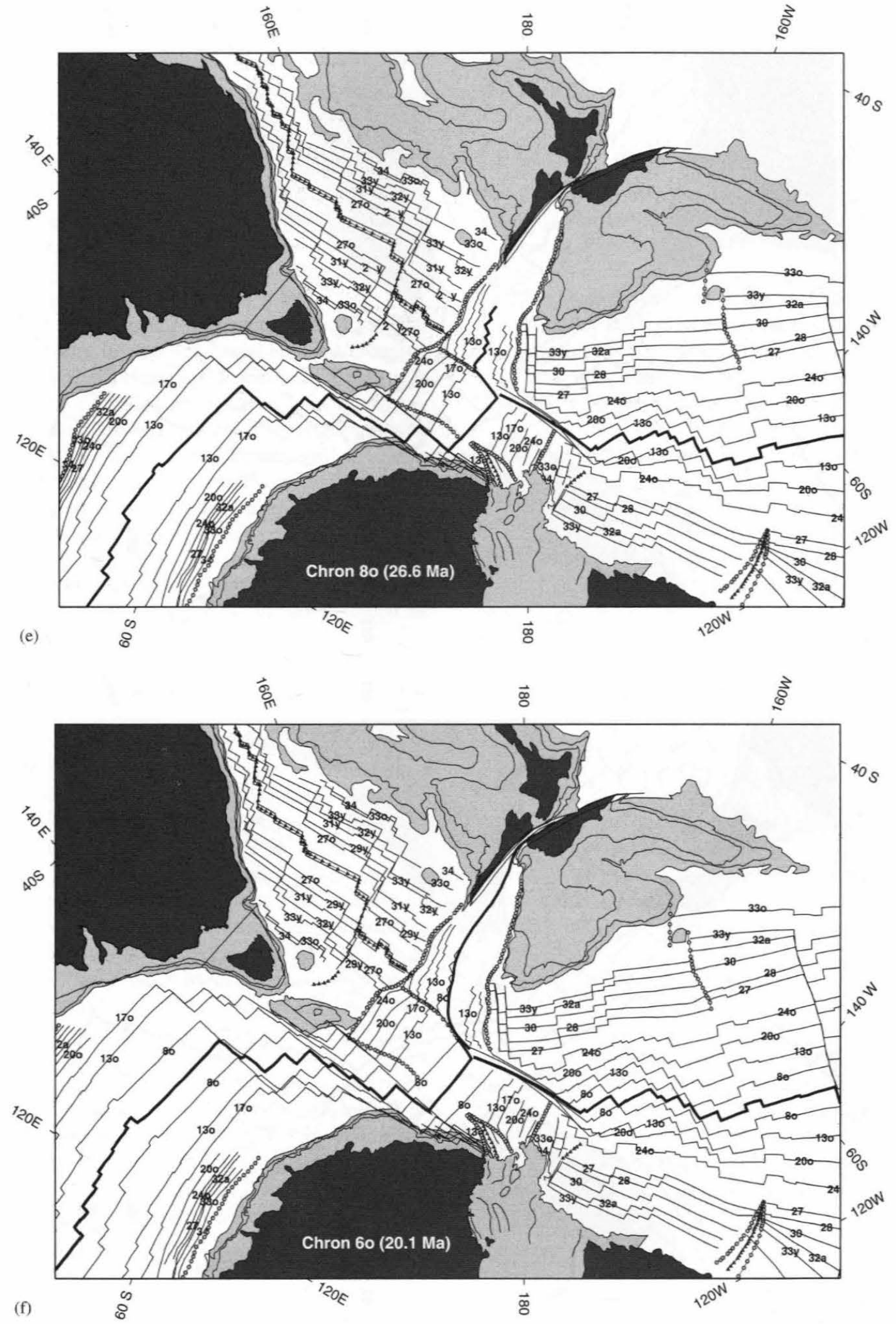

Figure 3. (Continued). 

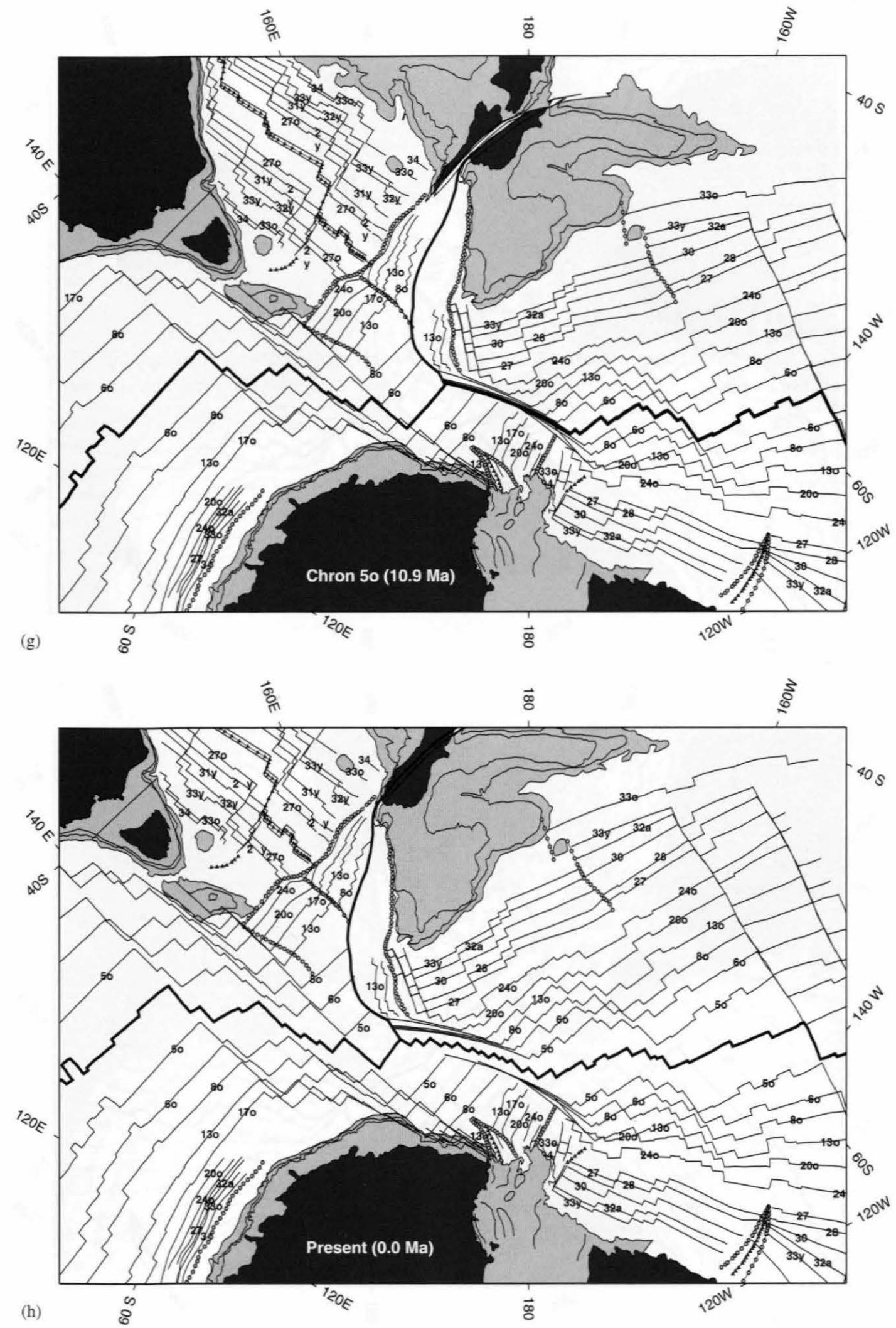

Figure 3. (Continued). 


\section{Chron 24o (53.3 Ma; Figure 3b)}

The basic plate configuration until Chron 24 was about the same as at Chron 27, with moderate spreading occurring in the Tasman Sea and on the Pacific-Antarctic ridge and very slow spreading on the SEIR. Between Chrons 27 and 24 the Iselin Bank has rotated $7^{\circ}$ counterclockwise about a pole in the western Ross Sea, forming the Iselin Rift. This rotation maintains the alignment of the splays of the Emerald FZ across the Pacific-Antarctic ridge. Iselin Bank has started to separate from Cape Adare and the northern Ross Sea basins have opened roughly $50 \mathrm{~km}$ in this time period.

Two significant tectonic changes occurred around Chron 24. First, spreading in the Tasman Sea ceased around Chron $24 \mathrm{y}$ (52 Ma), joining the Lord Howe Rise to the Australian plate. A boundary between the Pacific plate and Australian plate almost certainly would have developed at this time, perhaps cutting across the Challenger Plateau at the southeastern end of the Lord Howe Rise (otherwise the Pacific and Australia plates would have coalesced into a single large plate). Motion on this boundary would probably have been slow and predominantly strike slip until Chron 20. Second, there was a halving in spreading rate on the Pacific-Antarctic ridge which occurred about $55 \mathrm{Ma}$, a few million years before the cessation of spreading in the Tasman Sea [Larter et al., 2002].

\section{Chron 20o (43.8 Ma; Figure 3c)}

Between Chrons 24 and 20 there was slow spreading $(15 \mathrm{~mm} / \mathrm{yr})$ on the Pacific-Antarctic ridge and continued very slow spreading on the SEIR. As we noted above, an active plate boundary must have existed somewhere between the Campbell Plateau and Lord Howe Rise. Then, around Chron 20 (43.8 Ma), the location of the PacificAustralia Euler pole shifted such that the Pacific-Australia boundary from New Zealand southward was in extension, initiating spreading in the Emerald Basin and STOC region.

Chron 20 also marks the start of the main episode of Cenozoic East-West Antarctic separation and the initiation of seafloor spreading in the Adare Basin, northeast of Cape Adare. In our model, this coincides with a southward jump of the Antarctic-East Australia boundary from a position between the western and eastern pieces of the South Tasman Rise to a position west of the western fragment, thereby joining the two fragments into a single South Tasman Rise now fixed to Australia. Chron 20 is also roughly the time of a speed up on the SEIR, from very slow to slow. Chron 20 marks the establishment of a long transform fault connecting the southernmost spreading segment on the Pacific-Antarctic ridge to the Macquarie triple junction (Australia-Pacific-Antarctic). This long transform fault was a striking feature of this boundary until Chron 5 .

\section{Chron 13o (33.5 Ma; Figure 3d)}

Between Chrons 20 and 13 spreading continues to generate new crust between the Pacific and Australia plates in the Emerald Basin and STOC region. Spreading also continues in the Adare Basin recording the slow but continuous separation of East and West Antarctica. In our model the basins of the northern Ross Sea continue to open, separating the Iselin Bank still further from Cape Adare. Spreading on the SEIR accelerated around Chron 18 (40 Ma), setting the way for the much more rapid opening of the continental pieces blocking the Tasmanian Gateway. At Chron 13 the South Tasman Rise is just clearing the last piece of Antarctic continental margin, changing this boundary from a continent-continent strike-slip fault into an oceanic transform fault and opening a clear passageway for the Antarctic Circumpolar Current.

\section{Chron 80 (26.6 Ma; Figure 3e)}

Spreading continues at moderate rates $(20-30 \mathrm{~mm} / \mathrm{yr})$ on the SEIR and Pacific-Antarctic ridge. However, the motion between the Pacific and Australia plates is gradually becoming more transcurrent rather than extensional and Chron 8 is near the end of the time of magnetic anomaly formation in the Emerald Basin and STOC region. This may be roughly the time that motion started on the Alpine Fault in New Zealand. Chron 8 is also approximately the time that motion between East and West Antarctica ends.

\section{Chron 6o (20.1 Ma; Figure 3f)}

Spreading continues at moderate rates on the SEIR and Pacific-Antarctic ridge. Motion between the Australia and Pacific plates south of New Zealand has become predominantly strike slip and spreading has nearly ceased along the boundary between the Emerald Basin and STOC region.

\section{Chron 5o (10.9 Ma; Figure 3g)}

Spreading continues on the SEIR and Pacific-Antarctic ridge at a moderate rate. The boundary between the Australian and Pacific plates is dominated by strike slip motion taken up along the Macquarie Ridge complex. The transform fault connecting the southwesternmost spreading segment on the Pacific-Antarctic ridge to the Macquarie triple junction has grown to a length of over $1000 \mathrm{~km}$.

\section{Present (Figure 3h)}

Spreading rates have increased noticeably on the SEIR and Pacific-Antarctic ridges but are still moderate $(25-35 \mathrm{~mm} / \mathrm{yr})$. There has been a late Neogene clockwise rotation in 
spreading direction on both ridges. On the Pacific-Antarctic ridge this has resulted in the development of a staircase of small ridge segments and moderate length transform faults replacing the single long transform at the south end of the Pacific-Antarctic ridge.

\section{SUMMARY}

The reconstructions presented here document the separation of Australia, Antarctica and New Zealand in the Cenozoic and the development of a deepwater passageway between the South Tasman Rise and Antarctica. At Chron 27 $(61.1 \mathrm{Ma})$, Tasmania blocked the eastern end of the Australia-Antarctic Basin to deepwater circulation and the fragments of the South Tasman Rise were adjacent to Antarctica. The Iselin Bank was adjacent to Northern Victoria Land and the western Ross Sea Basins were much smaller. Between Chrons 27 and 20 (43.8 Ma) the width of the Australia-Antarctic Basin grew very slowly and the eastern end remained blocked to deepwater circulation by Tasmania and the saddle between Tasmania and the South Tasman Rise. The Iselin Bank was slowly separating from Northern Victoria Land and there was some extension in the western Ross Sea Basins. Chron 24 (53.3 Ma) saw the cessation of spreading in the Tasman Sea and a dramatic decrease in spreading rate on the Pacific-Antarctic ridge.

Around Chron 20 (43.8 Ma) there was a significant acceleration in the spreading rate on the SEIR, the western fragment of the South Tasman Rise separated from Antarctica, there was faster separation between East and West Antarctica, particularly in the Adare Basin, and spreading developed between the Pacific and Australian plates in the Emerald Basin and STOC region. A shallow passage through the gateway would have existed in the saddle between Tasmania and the South Tasman Rise. Around Chron 13 (33.5 Ma) the South Tasman Rise cleared the last promontory of the Antarctic continental margin, allowing the development of the Antarctic Circumpolar Current in the early Oligocene [Kennett et al., 1975; Exon, Kennett, Malone et al., 2001]. It should be noted that the latest studies (e.g. Barker, 2001) indicate that the other key gateway, the Drake Passage, opened several million years later. Separation between East and West Antarctica ceased around Chron 8 (26.6 Ma) which also roughly marked the time that motion between the Australia and Pacific plates became more transcurrent, leading to the development of the Macquarie Ridge into a primarily strike-slip boundary by Chron 5 (10.9 Ma).

Acknowledgments. We thank Rob Larter and Carmen Gaina for their helpful reviews and Neville Exon for his editorial suggestions. GMT software was used to produce the figures [Wessel and Smith,
1991]. This research was supported by NSF grants OPP-0126340 (UCSD) and OPP-0126334 (Caltech). California Institute of Technology Division of Geological and Planetary Sciences contribution number 8956 .

\section{REFERENCES}

Burnham, C. W., Importance of volatile constituents, in Evolution of Igneous Rocks, edited by H. D. Yoder, pp. 439-482, Princeton University Press, Princeton, N. J., 1979.

Burnham, C. W., Importance of volatile constituents, in Evolution of Igneous Rocks, edited by H. D. Yoder, pp. 439-482, Princeton University Press, Princeton, N. J., 1979.

Barker, P. F., Scotia Sea regional tectonic evolution: implications for mantle flow and paleocirculation, Earth-Science Reviews, $55,1-39,2001$.

Cande, S. C. and D. V. Kent, Revised calibration of the geomagnetic time scale, J. Geophys. Res., 100, 6093-6096, 1995.

Cande, S. C. and J. C. Mutter, A revised identification of the oldest sea-floor spreading anomalies between Australia and Antarctica, Earth Planet. Sci. Lett., 58, 151-160, 1982.

Cande, S. C., C. A. Raymond, J. M. Stock, and W. F. Haxby, Geophysics of the Pitman Fracture Zone and Pacific-Antarctic plate motions during the Cenozoic. Science, 270, 947-953, 1995.

Cande, S. C., J. M. Stock, R. D. Müller, and T. Ishihara, Cenozoic motion between East and West Antarctica, Nature, 404, 145-150, 2000a.

Cande, S. C., J. M. Stock, R. D. Müller, T. Ishihara, Two stages of Cenozoic separation in the western Ross Sea embayment [abstract], EOS Trans. Amer. Geophys. Union, 48, F1131, 2000b.

Cunningham, A. P., R. D. Larter, P. F. Barker, K. Gohl, and F. O. Nitsche, Tectonic evolution of the Pacific margin of Antarctica 2. Structures of the Late Cretaceous-Early Tertiary plate boundaries in the Bellingshausen Sea from seismic reflection and gravity, $J$. Geophys. Res., 107 (B12), EPM6, doi: 10.1029/ 2002JB001897, 2002.

Exon, N., A. M. G. Moore, and P. J. Hill, Geological framework of the South Tasman Rise, south of Tasmania, and its sedimentary basins, Australian J. Earth Sci., 44, 561-577, 1997.

Exon, N., J.-Y. Royer, and P. J. Hill, Tasmante cruise: swathmapping and underway geophysics south and west of Tasmania. Mar. Geophys. Researches, 18, 257-287, 1996.

Exon N., J. P. Kennett, M. Malone et al., Leg 189 Preliminary Report $\ddot{y}$ The Tasmanian Gateway between Australia and Antarctica $\ddot{y}$ Paleoclimate and Paleooceanography, ODP-TAMU website, 2001.

Gaina, C., R. D. Mller, J.-Y. Royer, J. Stock, J. Hardebeck, and P. Symonds, The tectonic history of the Tasman Sea: A puzzle with thirteen pieces. J. Geophys. Res., 103, 12,413-12,433, 1998.

Hayes, D. E. and J. Ringis, Seafloor spreading in the Tasman Sea, Nature, 243, 454-458, 1973.

Heinemann, J., J. Stock, R. Clayton, K. Hafner, S. Cande, and C. Raymond, Constraints on the proposed Marie Byrd Land-Bellingshausen plate boundary from seismic reflection data, J. Geophys. Res., 104, 25,321-25,330, 1999. 
IHO/IOC/CHS, GEBCO - General Bathymetric Chart of the Oceans (5th Edition), International Hydrographic Organization/ Intergovernmental Oceanographic Commission/ Canadian Hydrographic Service, Ottawa, Canada, 1984.

Ishihara, T., M. Tanahashi, M. Sato, M., and Y. Okuda, Preliminary report of geophysical and geological surveys of the West Wilkes Land Margin, Proc. NIPR Symp. Antarct. Geosci., 9, 91-108, 1996.

Keller, W.R., Cenozoic plate tectonic reconstructions and plate boundary processes in the Southwest Pacific, $\mathrm{Ph}$. D. thesis, California Institute of Technology, Pasadena, California, 92 p., 2003.

Kennett, J. P., R. E. Houtz, P. B. Andrews, A. E. Edwards, V. A. Gostin, M. Hajos, M. Hampton, D. G. Jenkins, S. V. Margolis, A. T. Ovenshine, and K. Perch-Nielsen, Cenozoic paleoceanography in the southwest Pacific Ocean, Antarctic glaciation, and the development of the Circum-Antarctic Current, in Initial Reports of the Deep Sea Drilling Project, vol. 29, edited by J. P. Kennett and R. E. Houtz et al., p. 1155-1169, U.S. Govt. Printing Office, Washington, D.C., 1975.

Lamarche, G., J.-Y. Collot, R. A. Wood, M. Sosson, R. Sutherland, and J. Delteil, The Oligocene-Miocene Pacific-Australia plate boundary, south of New Zealand: Evolution from oceanic spreading to strike slip faulting, Earth Planet. Sci. Lett., 148, 129-139, 1997.

Larter, R. D., A. P. Cunningham, P. F. Barker, K. Gohl, and F. O. Nitsche, Tectonic evolution of the Pacific margin of Antarctica 1. Late Cretaceous tectonic reconstructions, J. Geophys. Res, 107 (B12), EPM5, doi: 10.1029/2000JB000052, 2002.

Lawver, L. A. and L. M. Gahagan, Constraints on the timing of extension in the Ross Sea Region, Terra Antarctica, 1(3), 545$552,1994$.

Massell, C., M. F. Coffin, P. Mann, S. Mosher, C. Frohlich, C. S. Duncan, G. Karner, D. Ramsay, and J.-F. Lebrun, Neotectonics of the Macquarie Ridge Complex, Australia-Pacific plate boundary, J. Geophys. Res., 105, 13,457-13,480, 2000.

Mayes, C. L., L. A. Lawver, and D. T. Sandwell, Tectonic history and new isochron chart of the South Pacific, J. Geophys. Res., 95, 8543-8567, 1990.

Molnar, P., T. Atwater, J. Mammerickx, and S. M. Smith, Magnetic anomalies, bathymetry, and the tectonic evolution of the South Pacific since the late Cretaceous, Geophys. J. Roy. Astro. Soc., 40, 383-420, 1975.

Royer, J.-Y. and T. Chang, Evidence for relative motions between the Indian and Australian plates during the last $20 \mathrm{Myr}$ from plate tectonic reconstructions: implications for the deformation of the Indo-Australian plate, J. Geophys. Res., 96, 11779-11802, 1991.

Royer, J.-Y. and N. Rollet, Plate-tectonic setting of the Tasmanian region, Australian J. Earth Sci., 44, 543-560, 1997.

Royer, J.-Y. and D. T. Sandwell, Evolution of the Indian Ocean since the Late Cretaceous: Constraints from Geosat altimetry, J. Geophys. Res., 94, 13,755-13,782, 1989.

Sandwell, D. T. and W. H. F. Smith, Marine gravity anomaly from Geosat and ERS-1 satellite altimetry, J. Geophys. Res., 102, 10,039-10,054, 1997.

Sayers, J., P. A. Symonds, N. G. Direen, and G. Bernardel, Nature of the continent-ocean transition on the non-volcanic rifted margin of the central Great Australian Bight, in Non-volcanic rifting of Continental Margins: A comparison of evidence from Land and Sea, edited by R. C. L. Wilson, R. B. Whitmarsh, B. Taylor, and N. Froitzheim, Geol. Soc. London Special Publ., 187, 51-76, 2001.

Stock, J. M. and S. C. Cande, Tectonic History of Antarctic Seafloor in the Australia-New Zealand-South Pacific Sector: Implications for Antarctic Continental Tectonics, in Antarctica at the Close of a Millennium, edited by J. A. Gamble, D. N. B. Skinner, and S. Henrys, Roy. Soc. N. Z. Bull., 35, 251-259, 2002.

Stock, J. and P. Molnar, Uncertainties in the relative positions of the Australia, Antarctica, Lord Howe, and Pacific plates since the late Cretaceous, J. Geophys. Res., 87, 4697-4714, 1982.

Stock, J. and P. Molnar, Revised history of early Tertiary plate motion in the Southwest Pacific, Nature, 325, 495-499, 1987.

Sutherland, R., The Australia-Pacific boundary and Cenozoic plate motions in the SW Pacific: some constraints from Geosat data, Tectonics, 14, 819-831, 1995.

Tikku, A. and S. C. Cande, The oldest magnetic anomalies in the Australian-Antarctic basin: are they isochrons? J. Geophys. Res., 104, 661-677, 1999.

Tikku, A. and S. C. Cande, On the fit of Broken Ridge and Kerguelen plateau, Earth Planet. Sci. Lett., 180, 117-132, 2000 .

Veevers, J. J., Break-up of Australia and Antarctica estimated as mid-Cretaceous $(95 \pm 5 \mathrm{Ma})$ from magnetic and seismic data at the continental margin, Earth Planet. Sci. Lett., 77, 91-99, 1986.

Veevers, J. J., H. M. J. Stagg, J. B. Willcox, and H. L. Davies, Pattern of slow seafloor spreading ( $<4 \mathrm{~mm} /$ year) from breakup (96 Ma) to A20 (44.5 Ma) off the southern margin of Australia, BMR Journal of Australian Geol. Geophys., 11, 499-507, 1990.

Wessel, P. and W. H. F. Smith, Free software helps map and display data, EOS Trans. Amer. Geophys. Union, 72, 441-445, 1991.

Weissel, J. K. and D. E. Hayes, Magnetic anomalies in the Southeast Indian Ocean, in Antarctic Oceanology II: The Australian-New Zealand Sector, Antarctic Res. Ser, 19, edited by D.E. Hayes, pp. 165-196, AGU, Washington, D.C, 1972.

Weissel, J. K. and D. E. Hayes, Evolution of the Tasman Sea reappraised, Earth Planet. Sci. Lett., 36, 77-84, 1977.

Weissel, J. K., D. E. Hayes, and E. M. Herron, Plate tectonics synthesis: The displacements between Australia, New Zealand, and Antarctica since the Late Cretaceous, Marine Geology, 25, 231-277, 1977.

Wood, R., R. Herzer, R. Sutherland, and A. Melhuish, CretaceousTertiary tectonic history of the Fiordland margin, New Zealand, N. Z. J. of Geol. and Geophys., 43, 289-302, 2000.

Steven C. Cande, Scripps Institution of Oceanography, Mail Code 0220, La Jolla, CA 92093-0220, scande@ucsd.edu.

Joann M. Stock, Seismological Laboratory, Mail Stop 252-21, California Institute of Technology, Pasadena, CA 91125, jstock@gps.caltech.edu. 